\title{
高齢者腰椎変性すべり症手術治療成績の検討
}

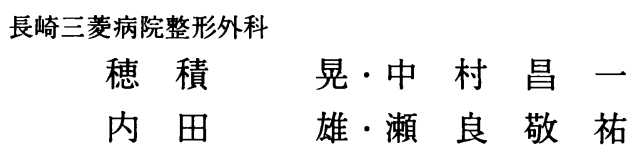

\section{Surgical Results of Degenerative Lumbar Spondylolisthesis in Aged Patients}

\author{
Akira Hozumi, Masakazu Nakamura, Takeshi Uchida, \\ and Keisuke Sera \\ Department of Orthopaedic Surgery, \\ Nagasaki Mitsubishi Hospital
}

\begin{abstract}
Between November 1989 and October 1998, 20 degenerative lumbar spondylolisthesis patients over 65-years were treated with posterior decompression surgery. The mean age at surgery was 70.5 years (range, 65 to 80 ) and the length of follow-up was 26.7 months (range, 7 to 40). These patients were divided into three groups (without fusion, posterolateral fusion (PLF), and PLF and pedicular screw system).

The clinical scores were evaluated retrospectively with the Japanese Orthopedic Asssociation low back pain rating score (JOA score). The JOA score was 13.0 preoperatively and 22.4 postoperatively (rate of improvement: $61.1 \%$ ) on average. Relatively good results were obtained in all groups. The best and consistent results in the group with PLF and pedicular screw system, the rate of improvement of which was over $50 \%$ in all cases.
\end{abstract}

Key words : Aged patient (高齢者), Surgical result (手術成績), Degenerative lumbal spondylolisthesis（腰椎変性すべり症）

\section{はじめに}

Instrumentation の普及に伴い, 腰椎変性すべり 症（以下 DS）に対する後側方固定術（以下 PLF）に 骨癒合率の上昇やすべりの矯正を目的として transpedicular screw system の併用が広く行われてい る.しかし社会的活動性が低下し, 骨粗珐症を含めた 全身的, 局所的合併症を有する高齢者 DSについては, いまだ固定すべきか否か議論の多いところである.

当院では, 高齢者 DS に対し，1992 年までは責任 病巣を中心とする後方除圧または, 後方除圧十後側方 固定（以下 PLF）を施行し, 1992 以降はこれらに Instrument を併用してきた。 そこで今回これら高齢
者 DS の術後成績を検討し本症に対する固定術，特に instrument の併用について検討を加えたので報告す る.

\section{対象および方法}

1989. 11 1998. 10 までの過去 10 年間に手術を施 行した 65 歳以上の高齢者 DS 20 例である. 男性 8 例, 女性 12 例，平均年齢 70.5 歳，術後追跡期間は 7 ケ月 $\sim 6$ 年 3 ケ月, すべり高位は L3 $: 4$ 例, L4 : 16 例で あった。

検討項目はすべり率, 不安定性の経年的変化, さら に術前術後の臨床症状の評価は日整会腰痛疾患治療成 績判定基準（以下 JOA score）を用い，平林法によ 
りその改善率を求めた。

また X 線学的評価として，すべり率は Taillard 法および Meyerding の分類を用いて行った. さらに 単純 X 線腰椎側面像において, すべり椎体下縁と下 位椎体上縁のなす角を椎間角とし, 椎間角の前後屈時 の差を計測して椎間可動域とした。これらを用い前屈 時後方開大が 5 度以上, 椎間可動域が 10 度以上, 前 後屈時すべりの変化が $3 \mathrm{~mm}$ 以上のものを不安定性 ありと判定した（図1).また椎間板の狭小化程度を 戸山ら ${ }^{2)}$ に従い, stage $1 \sim 4$ に分類した.

手術方法については椎弓切除術 : 6 例, 椎弓切除術 +PLF : 4 例, 椎弓切除術 +PLFに instrument 併 用例：10 例である. 使用 instrument は Spine sys- tem 6 例, Diapason 3 例, Moss miami system 1 例ですべて transpedicular screw system を用い ていた。

高齢者 DS 手術症例の内訳を表 1 に示す．高齡者で は必然的に多椎間病巣が増加し，すべり椎間のみの単 椎間病巣例は 20 例中 6 例であった，術前のすべりの 程度は Meyerding の分類で 1 度 : 18 例, 2 度 : 2 例, で最大 $35.1 \%$ のすべり率であった。術前不安定性は, 椎弓切除群 : 2 例, 椎弓切除 +PLF 群 : 3 例, instrument 使用群：6 例に認められた。椎間板の狭小 化程度は stage 1 が 6 例, stage 2 が 10 例, stage 3 が 3 例, stage 4 が 1 例であった.
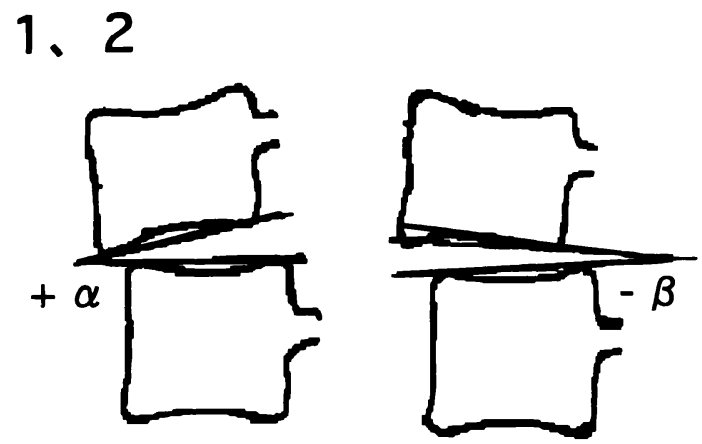

椎间可動域： $+\alpha-(-\beta)$

前屈時後方開大 $:+\alpha>5$ 度
3

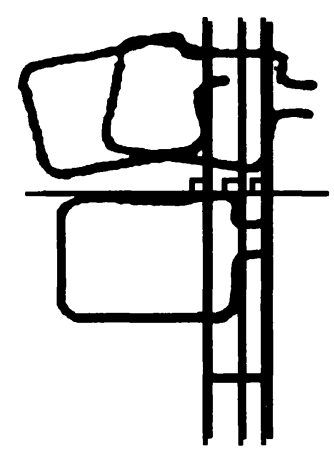

$3 \mathrm{~mm}$ Anterior translation $<3 \mathrm{~mm}$ Posterior translation

図 $1 \mathrm{X}$ 線学的検討による不安定性の指標

1 前屈時後方開大が 5 度以上

不安定性の指標 2 前後屈時の椎間可動域が 10 度以上

3 前後屈時のすべりの変化が $3 \mathrm{~mm}$ 以上

表 1 高齢者腰椎変性すべり症手術症例の内訳

\begin{tabular}{|c|c|c|c|c|c|c|c|c|c|c|c|}
\hline & \multirow{2}{*}{ 症例数 } & \multirow{2}{*}{$\begin{array}{l}\text { 年齢 } \\
\text { (平均) }\end{array}$} & \multicolumn{2}{|c|}{ 病巣椎間 } & \multicolumn{2}{|c|}{ すべり率* } & \multirow{2}{*}{$\begin{array}{c}\text { 不安定性 } \\
\text { あり }\end{array}$} & \multicolumn{4}{|c|}{ 椎間板狭小化程度 } \\
\hline & & & 単椎間 & 多椎間 & I 度 & II 度 & & I & II & III & IV \\
\hline 椎弓切除術 & 6 & 69.8 & 3 & 3 & 5 & 1 & 2 & 1 & 4 & 1 & 0 \\
\hline 椎弓切除術 + PLF & 4 & 74.0 & 0 & 4 & 4 & 0 & 3 & 0 & 4 & 0 & 0 \\
\hline $\begin{array}{l}\text { 椎弓切除術 + PLF } \\
\text { + Instrumentation }\end{array}$ & 10 & 70.0 & 3 & 7 & 9 & 1 & 6 & 5 & 2 & 2 & 1 \\
\hline
\end{tabular}

*Meyerding の分類を使用 


\section{結果}

〔X 線所見〕術前後におけるすべり率の変化は instrument 併用群では術後 3 ケ月で $2.7 \%$ の矯正損失 を認めたが最終観察時に術前のすべりを上回るものは なかった．椎弓切除群および椎弓切除＋PLF 群では 最大で $28.5 \%$ と，社会的活動性の減じた高齢者にお

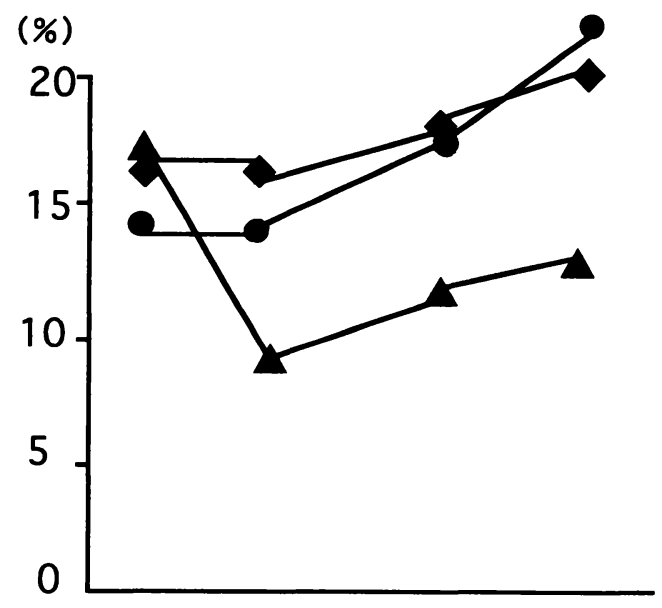

\section{術前 術直後 術後 $3 M$ 最終時}

図 2 すべり率の推移

椎弓切除術

椎弓切除術 + PLF

- 椎弓切除術 + PLF + Instrumentation

\section{(点)}

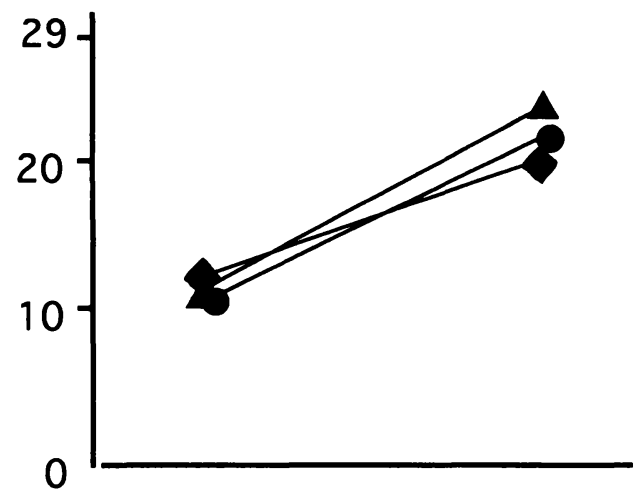

図 4 JOA score
いてもすべりの進行が認められた（図 2)，椎間可動 域についてはすべての群で隇少しており，不安定性の 増強したものは 1 例もなかった。 instrument 併用群 では術後椎間可動域が 0.7 度と最も小さく，何らかの 固定術を併用したものの方が, 可動域の減少が明らか に大きかった（図 3)．PLF 施行例の術後 1 年の時点 での骨㾑合率については, instrument 非併用群の 1

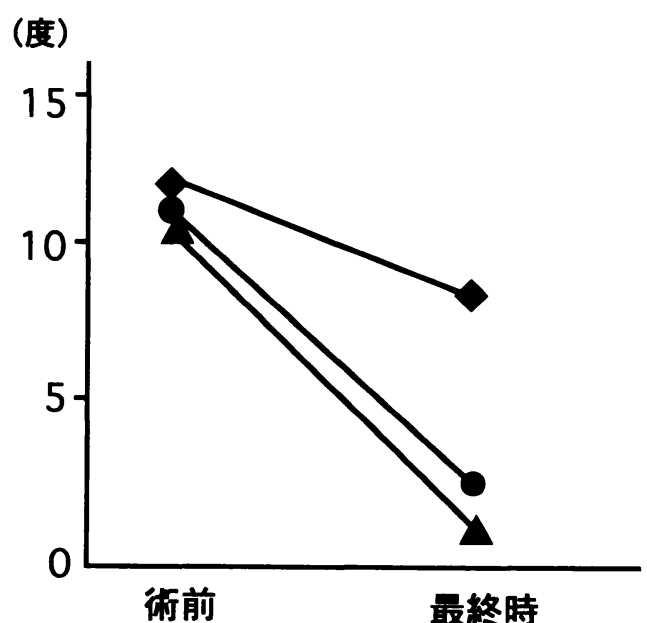

図 3 椎間可動域の推移

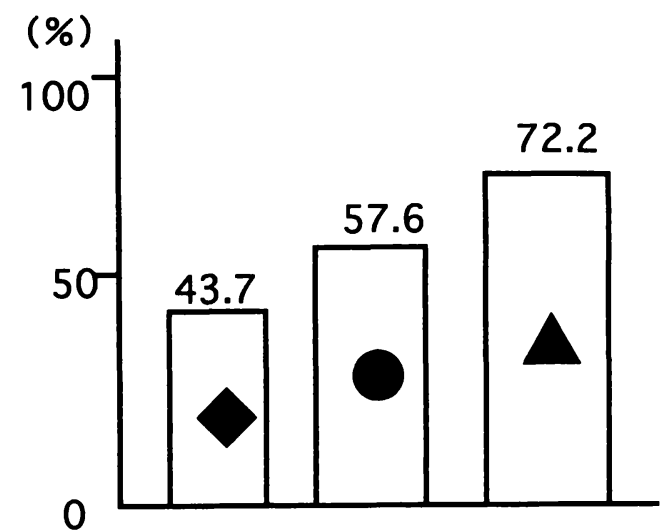

図 5 平林法による改善率 
例に偽関節例を認めたが，その他は全例良好であり， instrument 併用群の 1 例に抜釘術を施行していた。

〔臨床症状〕JOA score, 改善率ともに instrument 併用群, 椎弓切除 + PLF 群, 椎弓切除群の順に高かっ た（図 4, 図 5). 腰痛 scoreについてもその改善率 でみると何らかの固定を併用したものの方が高く，特 にinstrument 併用群が最も高かった（図 6)。また その他の詳細項目についても同様の結果が得られた。

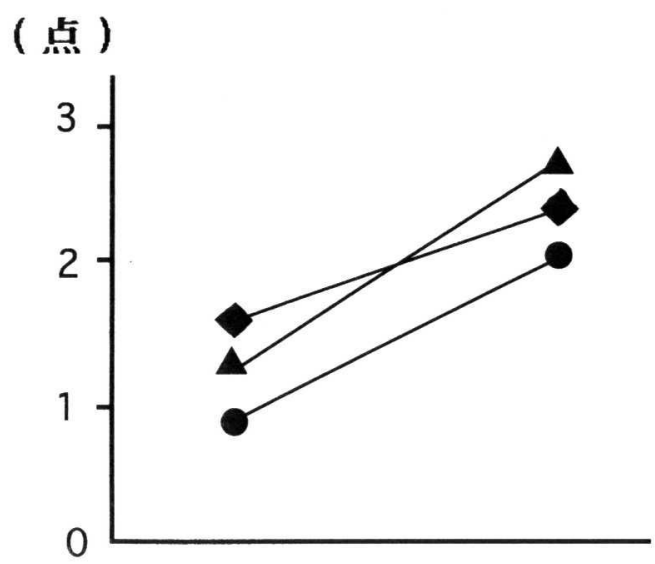

図 6 腰痛 score

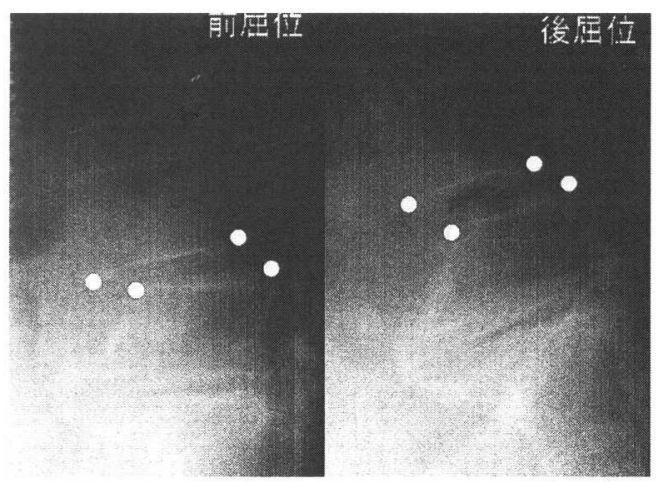

術 前

\section{症 例 供 覧}

（症例 1） 65 歳女性. L4/5すべり. 術前 $100 \mathrm{~m}$ 以下 の間久性跛行を認めた，椎間関節を温存した椎弓切除 術を施行した. 術後歩行能力の改善は得られたが, 他 の項目については明らかな改善は認められなかった。 術前 JOA score は 13 点, 術後 18 点, 改善率 $31.3 \%$. X 線学的には術前椎間板高は stage 2, すべり率は術 前 $17.4 \%$, 術後 $22.2 \%$ であった（図 7).

（症例 2） 72 歳男性. L3/4 すべり。腰痛及び $100 \mathrm{~m}$ 以下の間欠性跛行を認めた。椎弓切除に加え PLF を 施行した. 術後すべりの進行が認められたが歩行能力, 腰痛, 共に改善した. 術前 JOA score 7 点, 術後 18 点. 改善率 $50 \%$ 。X 線学的には術前, 椎間板高は stage 2 ，すべり率は術前 $14.6 \%$ ，術後 $28.5 \%$ また 単純 X 線正面像で PLF 偽関節例と判定した（図 8).

（症例 3）67歳男性. L4/5すべり。術前のすべり率 は $17.8 \%$ 椎間板高は stage 2 . 単純 X 線上, 明らか に不安定性を有していたＰＬFに instrumentを併 用した椎弓切除術を施行した。術後不安定性は消失し 骨癒合も良好である. 術前 JOA score 11 点, 術後 28 点. 改善率 $94.4 \%$. すべり率は術前 $17.8 \%$, 術後 15.5\%であった（図 9).

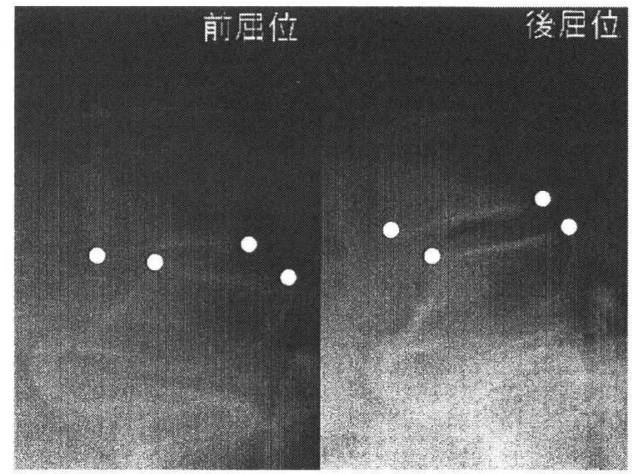

術 後

図 7 症例 1 


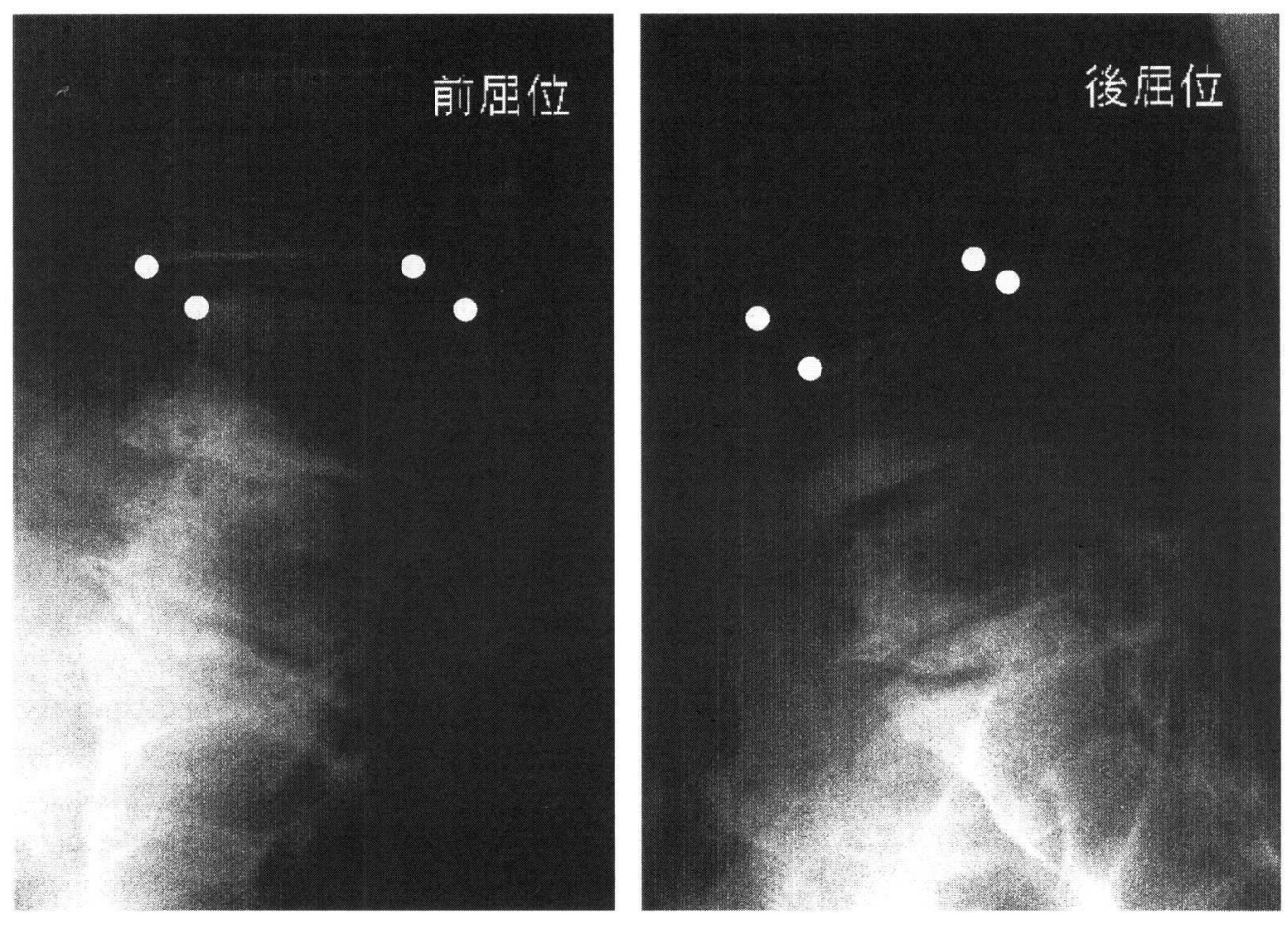

術 前

図 8-(1) 症例 2

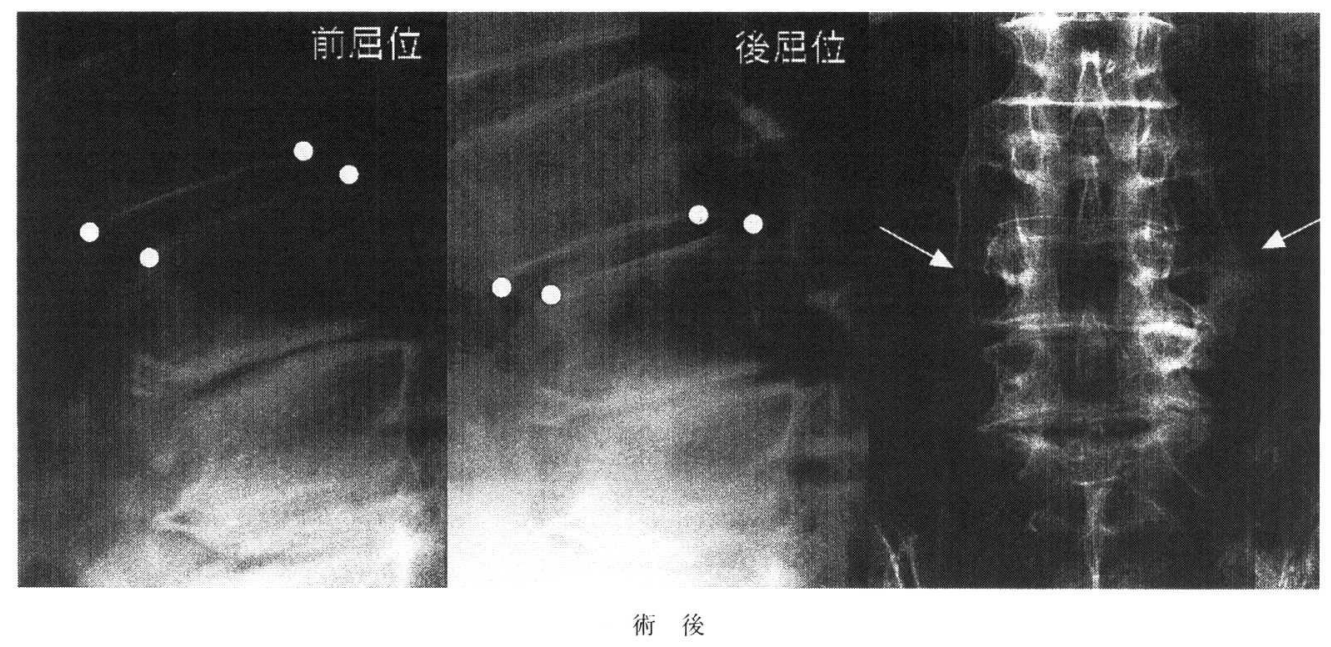

図 8 -(2) 症例 2 

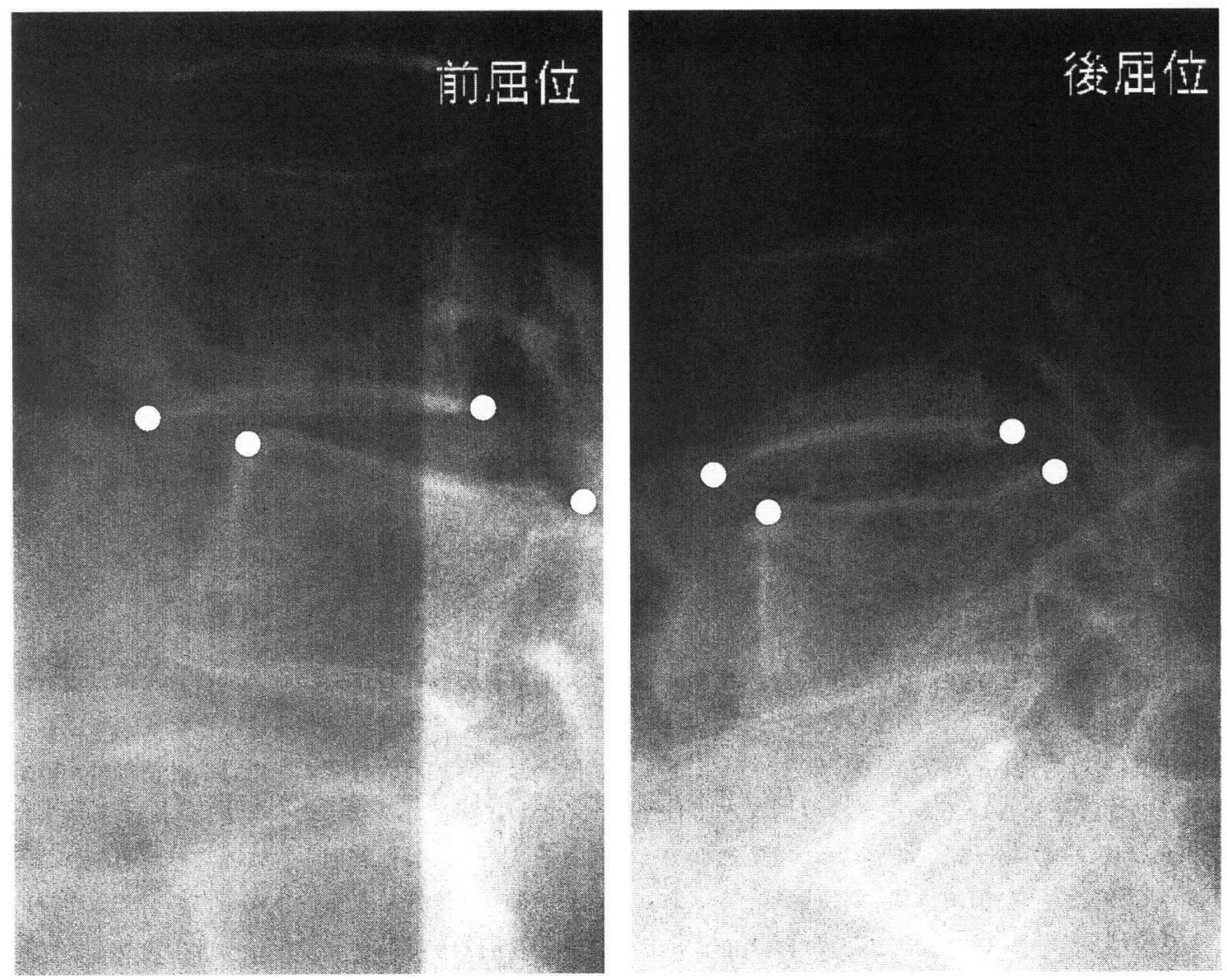

術 前

図 9 -(1) 症例 3

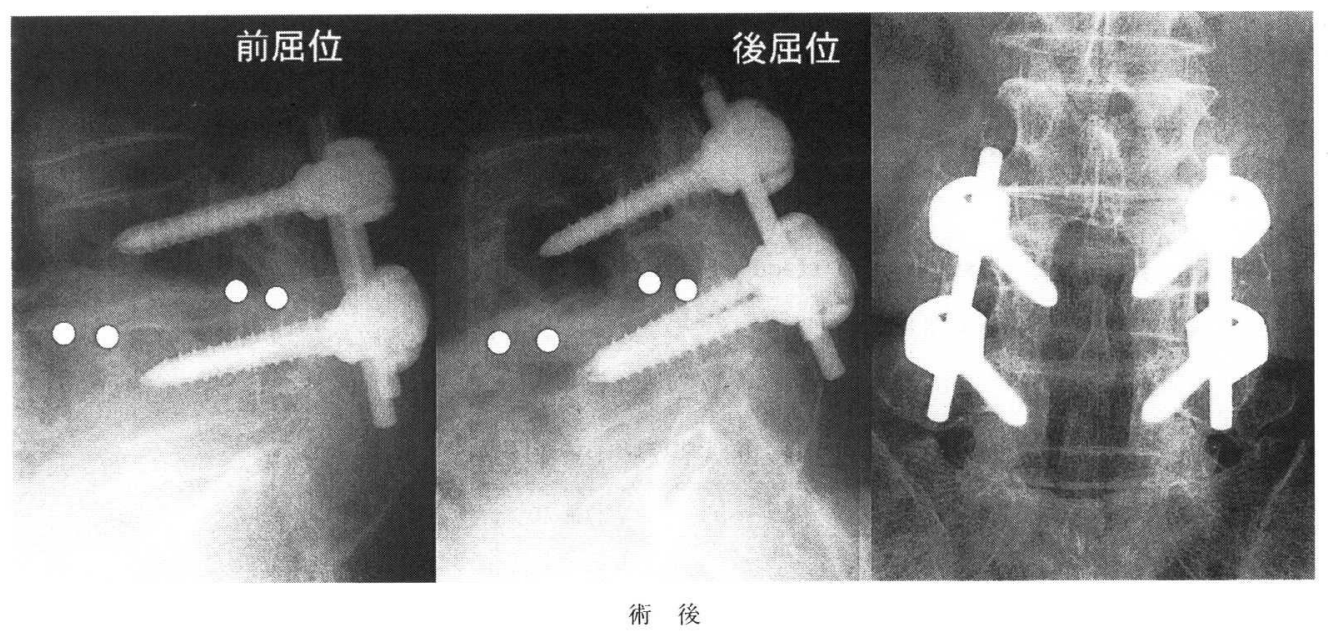

図 9 -(2) 症例 3 


\section{考察}

高齢者腰部脊柱管狭窄症の手術療法には, 後方除圧, とくに構築学的損失の少ない開空術の適応が一般的で ある。しかしすべりと不安定性を有する高齢者 DSに 対しては後方除圧単独で問題はないのか, やはり高齢 者と言えども固定術を併用すべきなのか, 現在でも未 解決の点である。川原ら ${ }^{1)}$ の報告によるとすべりの程 度と椎間板の狭小化程度から病期分類を行い, その病 期に応じて手術治療方針を決定すべきである（図 10), と述べ，また戸山ら ${ }^{2)}$ は椎間板狭小化程度が stage 1 ないし stage 2 に相当する症例に対してはすべりの 進行が認められ，たとえ高齢者であっても固定術の併 用が望ましいと述べている，今回の我々の調査では， 椎間板狭小化程度から分類すると stage 2 に相当す る症例が 11 例と過半数を占め, 高齢者と言えどもす ベりの進行が認められた。しかし臨床症状と画像所見 は一定の相関は認められなかった。

各術式別の改善率についてみると椎弓切除群では $31.3 \% \sim 66.7 \%$, 平均 $43.7 \%$, 椎弓切除 P P PF 群で は $38.5 \% \sim 75.0 \%$, 平均 $57.6 \%$ と比較的良好ではあ るが，大きなばらつきを認めた。一方 instrument 併 用群では $53.8 \% \sim 100.0 \%$, 平均 $72.2 \%$ とすべての症

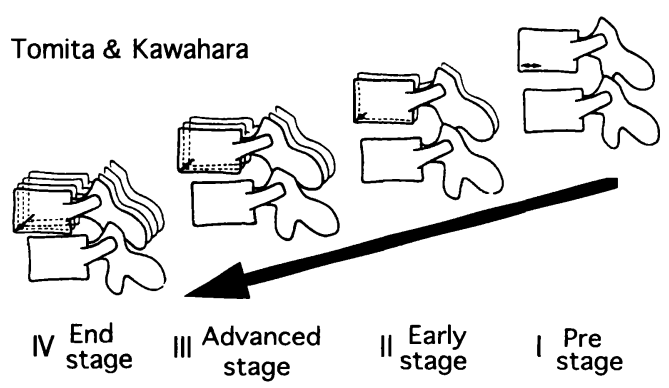

図10 腰椎変性すべり病期分類
例で $50 \%$ を上回っていた（表 2).

一般に DS は, 加齢現象に伴う椎間板変性により不 安定性が出現しこれに椎間関節の形態異常が伴うと 前方すべりを制御できずに発生する。椎間関節はすべ りを制御し脊椎の安定性に重要であるが, すでに形態 異常がみられる症例に対して, 可及的椎間関節温存が どこまですべりの制御に関与するかは疑問である。さ らに術前所見から後方除圧単独による手術適応基準を 決定することはきわめて困難と考えられる．一方 instrument を併用することは，後方からの広範な除圧 と固定が可能であり, 術後の不安定性を懸念する必要 性が少ない.

今回の我々の調査でも instrument 併用群はすべて の症例で改善率が $50 \%$ を上回っており，安定した結 果が得られた。

骨粗鬆症への適応と, 全身的合併症等により手術侵 襲の小さい手術法を選択することは妥当である。しか し高齢者というだけで，また社会的活動性が低いと言 うだけで手術法を選択すべきではない，高齢者に再手 術をすることは，初回手術にくらべて明らかに全身的， 局所的条件が悪くなる. 本疾患においては全身的に問 題のない限り固定術を併用した方がよりよい結果が得 られるものと考えられた。

$$
\text { ま と め }
$$

(1) 65 歳以上の高齢者 DS の手術治療成績について 報告した。

(2)高齢者といえどもPLFに加え instrumentを併 用した方が術後成績が安定して良好な結果がえられた。

\section{参 考 文 献}

1）川原範夫ら：腰椎変性すべり症の病期と術式選択。臨 整外, $32: 1283-1289,1997$.

2）戸山芳昭ら：高齢者腰椎変性すべり症に対する手術法 の選択. 整形外科, 43:1837-1846, 1992.

表 2 術式別詳細項目の推移

\begin{tabular}{l|c|c|c}
\hline \hline & 腰痛 score & 歩行能力 & 改善率 (平均)〔\%] \\
\hline 椎弓切除術 & $1.5 \rightarrow 2.2$ & $0.5 \rightarrow 2.3$ & $31.3 \sim 66.7(43.7)$ \\
\hline 椎弓切除術 + PLF & $0.8 \rightarrow 2.0$ & $0.7 \rightarrow 2.0$ & $38.5 \sim 75.0(57.6)$ \\
\hline $\begin{array}{l}\text { 椎弓切除術 + PLF } \\
+ \text { Instrumentation }\end{array}$ & $1.2 \rightarrow 2.7$ & $0.4 \rightarrow 2.2$ & $53.8 \sim 100.0(72.2)$ \\
\hline
\end{tabular}

